\title{
Quality characteristics and antioxidant activities of 'Sikhye' containing different amounts of Jerusalem artichoke extract
}

\author{
Hye-Sook Kim ${ }^{1}$, Eun-Sun Hwang ${ }^{1,2 *}$ \\ ${ }^{1}$ Department of Human Ecology, Major in Nutrition and Culinary Science, Hankyong National University, \\ Anseong 17579, Korea \\ ${ }^{2}$ School of Wellness Industry Convergence, Major in Food and Nutrition, Hankyong National University, \\ Anseong 17579, Korea
}

\section{돼지감자 추출물을 첨가하여 제조한 식혜의 품질 특성 및 항산화 활성}

\author{
김혜숙 ${ }^{1} \cdot$ 황은선 $^{1,2 *}$ \\ ${ }^{1}$ 한경대학교 생활과학과 영양조리과학전공, ${ }^{2}$ 한경대학교 웰니스산업융합학부 식품영양학전공
}

\begin{abstract}
This work investigated the quality characteristics and antioxidant activities of 'Sikhye' containing $0,25,50$, and $100 \%$ Jerusalem artichoke extracts (JAE) instead of water. The highest moisture content of 'Sikhye' was 82.91-87.93\% without JAE addition, which generally decreased the moisture content. There were no statistically significant differences in the crude protein and fat contents of 'Sikhye' as functions of the added JAE content. In proportion to the added JAE content, the sugar content, acidity and turbidity of 'Sikhye' increased, and the pH generally decreased. In chromaticity determination, the lightness decreased and redness and yellowness increased with increasing the level of JAE, and the total polyphenol and flavonoid contents increased. The antioxidant activities measured using DPPH and ABTS radical scavenging activities and reducing powder were significantly higher than that of the control, and proportionally increased as the amount of JAE increased. These results provide basic data for the development of 'Sikhye' supplemented with Jerusalem artichoke.
\end{abstract}

Keywords : Jerusalem artichoke, 'Sikhye', quality characteristics, antioxidant activity

\section{서 론}

식혜는 보리의 싹을 틔워 만든 엿기름 가루를 물과 함께 섞어 추출한 후에, 멥쌀이나 찹쌀로 지은 고두밥을 넣고 적당 한 온도를 유지하면서 엿기름에 함유된 맥아효소로 쌀 전분 을 분해 및 당화시켜 제조한 우리나라의 대표적인 전통 음료 이다(Choi 등, 2001; Suh 등, 1997). 밥알을 띄어서 먹는 것 을 식혜라고 하고 밥알을 모두 건져내고 액체만 마시는 것을 감주라고 부른다(Lee와 Jun, 1976; Park, 2006). 초기에는 고
두밥과 엿기름만으로 식혜를 제조했으나, 1924년 이후에는 설탕을 첨가한 기록이 있고(Suh 등, 1997), 현재는 거의 설탕 을 첨가하여 식혜를 만들고 있다. 식혜는 전분질의 분해 및 당화과정을 거치면서 소화가 잘 되고, 섬유질 함량이 높아 변 비 예방에 효과가 있으며(Park 등, 2009; Yang 등, 2016), 식 혜 속에 함유된 올리고당류들이 장내 유익균들을 증식시켜 장 건강에 도움이 되는 것으로 알려져 있다(Seo 등, 1997). 최근에는 호박, 인진쑥, 섬애약쑥, 조릿대, 헛개나무, 커피박 등에서 유용한 성분들을 추출하여 식혜 제조에 사용하는 물

*Corresponding author. E-mail : ehwang@hknu.ac.kr, Phone :+82-31-670-5182, Fax : +82-31-670-5189

Received 04 May 2021; Revised 16 July 2021; Accepted 07 September 2021.

Copyright (c) The Korean Society of Food Preservation.

This is an Open Access article distributed under the terms of the Creative Commons Attribution Non-Commercial License (http://creativecommons.org/licenses/by-nc/4.0) which permits unrestricted non-commercial use, distribution, and reproduction in any medium, provided the original work is properly cited. 
대신 첨가한 식혜들이 소개되고 있다(Park, 2014; Seo, 2016; Shin 등, 2017; Song과 Hwang, 2016).

돼지감자(Jerusalem artichoke, Helianthus tuberosus L.)는 북아메리카가 원산지인 다년생 식물로(Ben Chekroun 등, 1996), 수분, 온도, 토양 등에 구애받지 않고 척박한 환경조건 에서도 잘 자라고, 병해충에 대한 저항성이 강해 우리나라를 비롯한 전 세계적으로 널리 재배되고 있다(Kim, 2015; Slimestad 등, 2010). 돼지감자에는 과당(fructose)의 중합체 로 알려진 난소화성의 이눌린이 다량 함유되어 있다(Bornet, 1994; Kelly, 2008). 이눌린(inulin)은 위(胃)에서 분해되지는 않고, 장으로 이동하여 장내 미생물의 환경개선, 변비 완화, 장 질환 예방, 혈청 콜레스테롤과 혈청 지질 함량을 낮추는 효과가 있다(Baltacioglu와 Esin, 2012; Bornet, 1994). 이눌 린은 영양소의 소화와 흡수를 지연시키며 포만감을 주며, 체 내에서 흡수되지 않기 때문에 다이어트에 효과적이고, 비타 민과 무기질이 풍부하여 다양한 기능성 식재료로 충분한 가 치가 있는 물질이다(Ahmed와 Rashid, 2019). 돼지감자는 단 맛을 갖고 있지만, 일반적인 탄수화물에 비해 혈당 상승 폭이 크지 않으므로 당뇨병 식이에 적합하고, 다양한 기능성 물질 을 함유하고 있어 암 예방 등의 건강 증진 효과도 보고되고 있다(Ahmed와 Rashid, 2019; Shao 등, 2020).

돼지감자는 수분이 많고 쉽게 변질되는 특성 때문에 오래 보관하기 어렵고, 특유의 냄새와 아린 맛이 있어 생으로 섭취 하기보다는 가공용으로 개발하는 것이 필요하다(Jung과 Shin, 2016). 현재는 신선한 돼지감자를 즙의 형태로 제조하거나, 건조시켜 차, 분말, 환으로 활용하여 섭취하는 것이 보편적이 다. 따라서 돼지감자가 지닌 항산화, 항당뇨 및 건강에 도움 이 되는 특성을 활용한 다양한 형태의 가공식품을 개발하여 돼지감자의 섭취를 증진시키기 위한 연구가 필요하다. 현재 까지 돼지감자를 국수, 설기떡, 스펀지케이크, 머핀, 쿠키, 묵 등에 첨가하거나, 차의 형태로 제조하여 품질 및 관능적인 특 성을 분석하고, 항산화 효능을 탐색한 연구들이 일부 진행되 었으나(Hwang 등, 2019; Kim 등, 2014; Park, 2010; Park 등, 2013; Park, 2014; Shin 등, 1991; Shin과 Chung, 2019), 돼지 감자를 식혜 제조에 활용한 연구는 이루어지지 않았다.

따라서 본 연구에서는 다양한 생리활성물질이 풍부하고, 항산화 활성이 우수한 돼지감자 추출액을 다양한 비율로 첨 가하여 전통적인 방법으로 식혜를 제조한 후 이화학적 품질 특성, 항산화 물질의 함량 및 항산화 활성을 측정함으로써 식 혜 제조에 돼지감자의 적용 가능성을 탐색하였다.

\section{재료 및 방법}

\section{실험재료 및 시약}

본 연구에 사용한 볶은 돼지감자(Joehub Co., Ltd., Yeongcheon,
Korea), 쌀(Hongseong, Korea), 백설탕(CJ Cheiljedang, Incheon, Korea), 엿기름가루(Good \& Food, Gimhae, Korea) 은 시판품을 구입하여 사용하였다. 식혜 제조는 정수기용 정 제수를 사용하였다. 사용된 시약들은 Sigma-Aldrich Co.(St. Louis, MO, USA), Biozoa Biological Supply Co.(USA), Samchun Pure Chemical Co., Ltd.(Pyeongtaek, Korea), Junsei Chemical Co., Ltd.(Tokyo, Japan)에서 구입하였다. Folin-Ciocalteu's phenol reagent, 1,1-diphenyl-2-picrylhydrazyl (DPPH), gallic acid, catechin과 sodium phosphate monobasic, potassium ferricyanide, ferric chloride는 Sigma-Aldrich Chemical Co.(St Louis, MO, USA)에서, 2,2'-azino-bis(3ethylbenzothiazoline-6-sulfonic acid) diammonium salt(ABTS) 는 Fluk (Heidelberg, Germany)에서 구입하였다. 그 외 품질 및 항산화 활성을 측정하기 위해 사용한 시약들은 SigmaAldrich Chemical Co.와 Junsei Chemical Co., Ltd.(Tokyo, Japan)에서 구입하여 사용하였다.

\section{돼지감자 및 엿기름 추출물 제조}

돼지감자는 흐르는 물에서 깨끗이 씻어 볶은 돼지감자 $600 \mathrm{~g}$ 에 물 $6 \mathrm{~L}$ 를 넣고 $60^{\circ} \mathrm{C}$ 를 유지하면서 2시간 동안 열수 추출한 후 스테인리스 스틸 체망 위에 거즈로 걸러 추출물을 제조하였다. 엿기름가루 $600 \mathrm{~g}$ 을 면주머니에 넣고 $40^{\circ} \mathrm{C}$ 의 물 $6 \mathrm{~L}$ 를 넣어 2 시간 동안 20 분 간격으로 주물러서 엿기름 추출 물을 얻었다. 엿기름 추출물의 입자가 가라앉도록 3 시간 동안 실온에 정치시켜 얻은 맑은 상등액을 식혜의 당화에 사용하였 다. 예비실험을 통하여 Table 1과 같은 배합비로 식혜를 제조 하였다. 쌀을 3 회 세척하여 전기압력밥솥(CRP-HNXF $1020 \mathrm{FB}$, Cuckoo, Yangsan, Korea)에 넣고 쌀과 동량의 물을 첨가하 여 고두밥을 지었다. 식힌 고두밥에 당화를 촉진시키기 위해 설탕을 첨가한 후에 10 배의 엿기름 추출물을 넣어 $60^{\circ} \mathrm{C}$ 에서 5 시간 당화시킨 후 $100^{\circ} \mathrm{C}$ 에서 5 분 끓인 후 냉각시켜 식혜를 완성하였다. 완성된 식혜는 용도별로 나누어 담고, $4^{\circ} \mathrm{C}$ 에서 저장하면서 실험하였다.

\section{일반성분 함량 측정}

식혜의 일반성분은 $\mathrm{AOAC}(1995)$ 의 방법에 따라 분석하였 다. 수분은 $105^{\circ} \mathrm{C}$ 드라이오븐(Eyela, Tokyo, Japan)에서 상압 건조법으로 건조하여 정량하였고, 조회분은 $600^{\circ} \mathrm{C}$ 의 회화로 (Kukje, Seoul, Korea)에서 직접회화법으로 측정하였다. 조단 백질은 자동 단백질 분석기(Kjeltec 2400 AUT, Foss Tecator, Eden Prairie, MN, USA)를 이용하여 semimicro-Kjeldhl법으 로 분석하였고, 조지방은 Soxhlet 추출기(Soxtec System HT 1043, Foss Tecator, Eden Prairie, MN, USA)를 사용하여 diethyl ether로 추출하여 정량하였다. 
Table 1. Formula for 'Sikhye' made with different amounts of Jerusalem artichoke extract

\begin{tabular}{|c|c|c|c|c|}
\hline \multirow{2}{*}{ Ingredients } & \multicolumn{4}{|c|}{ Jerusalem artichoke extract $(\%)^{1)}$} \\
\hline & 0 & 25 & 50 & 100 \\
\hline Cooked rice $(\mathrm{g})$ & 200 & 200 & 200 & 200 \\
\hline Malt powder (g) & 200 & 200 & 200 & 200 \\
\hline Water $(\mathrm{mL})$ & 2,000 & 1,500 & 1,000 & 0 \\
\hline Jerusalem artichoke extract $(\mathrm{mL})$ & 0 & 500 & 1,000 & 2,000 \\
\hline Sugar (g) & 60 & 60 & 60 & 60 \\
\hline
\end{tabular}

${ }^{1)}$ Jerusalem artichoke extract $(25,50$ and $100 \%)$ was added based on the total volume of water.

\section{당도, 산도, $\mathrm{pH}$ 및 탁도 측정}

당도, 산도, $\mathrm{pH}$ 및 탁도 측정을 위해 식혜 시료를 13,500 $\times g$ 에서 10 분간 원심분리(Mega 17R, Hanil Co., Incheon, Korea)하여 상등액을 얻었다. 당도는 당도계(PR-201 $\alpha$, Atago Co., Tokyo, Japan)로 측정하였다. 산도는 식혜 상등액 10 $\mathrm{mL}$ 가 $\mathrm{pH}$ 8.3까지 도달하는데 소요된 $0.1 \mathrm{~N} \mathrm{NaOH}$ 양 $(\mathrm{mL})$ 을 citric acid 함량으로 환산하여 나타내었다. $\mathrm{pH}$ 는 $\mathrm{pH}$ meter (Ion S220, Mettler-Toledo, Schwerzenbach, Switzerland)로 측정하였다. 탁도는 spectrophotometer (Infinite M200 Pro, Tecan Group Ltd. San Jose, CA, USA)를 사용하여 $550 \mathrm{~nm}$ 에서 흡광도를 측정하였다.

\section{색도 측정}

식혜물과 식혜 밥알의 색도는 시료를 지름 $50 \mathrm{~mm}$ 의 petri dish에 넣고 명도( $\mathrm{L}^{*}$, lightness), 적색도(a*, redness), 황색도 ( $\mathrm{b}^{*}$, yellowness)를 색차계(Chroma Meter CR-400, Minolta, Tokyo, Japan)로 측정하였다. 백색 표준판을 사용하여 $\mathrm{L}^{*}$, $a^{*}, b^{*}$ 값의 표준색을 각각 $97.10,+0.24,+1.75$ 로 맞춘 후에 시료의 색도를 측정하였다.

\section{총폴리페놀 및 총플라보노이드 함량 분석}

식혜 시료 $0.5 \mathrm{~mL}$ 에 $2 \mathrm{~N}$ Folin-Ciocalteu's 시약 $0.5 \mathrm{~mL}$ 를 혼합한 뒤 3 분간 실온에서 반응시킨 후, $2 \%$ sodium carbonate $1.5 \mathrm{~mL}$ 를 첨가한 뒤 2시간 동안 암소에서 반응시 켰다. 반응물은 spectrophotometer를 이용하여 $760 \mathrm{~nm}$ 에서 흡 광도를 측정하였다. 식혜에 함유된 총폴리페놀 함량은 gallic acid의 표준곡선(6.25-100 $\mu \mathrm{g} / \mathrm{mL}$ )으로 식혜 $100 \mathrm{~mL}$ 당 gallic acid equivalent (GAE)로 표시하였다.

총플라보노이드 함량은 식혜 시료 $1 \mathrm{~mL}$ 와 $2 \%$ aluminium chloride methanolic solution $1 \mathrm{~mL}$ 를 혼합하여 실온에서 15 분 동안 반응시킨 후에 $430 \mathrm{~nm}$ 에서 흡광도를 측정하였다. 식 혜에 함유된 총플라보노이드 함량은 quercetin의 표준곡선
(6.25-100 $\mu \mathrm{g} / \mathrm{mL})$ 을 이용하여 식혜 $100 \mathrm{~mL}$ 당 quercetin equivalent(QE)로 표시하였다.

\section{항산화 활성 측정}

식혜의 항산화 활성은 Cheung 등(2003)의 방법을 이용한 $\mathrm{DPPH}$ 라디칼 소거활성, Re 등(1999)의 방법을 약간 변형한 ABTS 라디칼 소거활성 및 Oyaizu(1986) 방법을 이용한 환 원력으로 측정하였다. DPPH 라디칼 소거활성을 측정하기 위해 식혜 $100 \mu \mathrm{L}$ 를 96-well plate에 넣고 $0.2 \mathrm{mM} \mathrm{DPPH}$ 용 액 $100 \mu \mathrm{L}$ 를 첨가한 후 $37^{\circ} \mathrm{C}$ 에서 30 분간 반응시켰다. 515 $\mathrm{nm}$ 에서 spectrophotometer로 흡광도를 측정하고, 아래 식에 의해 계산하였다.

$$
\begin{aligned}
& \mathrm{DPPH} \text { 라디칼 소거활성 }(\%)= \\
& (1 \text { - 시료첨가구의 흡광도 / 시료 무 첨가구의 흡광도 }) \times 100
\end{aligned}
$$

$\mathrm{ABTS}$ 라디칼 소거활성은 $7.0 \mathrm{mM}$ ABTS와 $2.45 \mathrm{mM}$ potassium persulfate를 혼합하여 $\mathrm{ABTS}^{+}$을 형성할 수 있도록 빛을 차단한 곳에서 24 시간 동안 반응시켰다. 시료의 $\mathrm{ABTS}$ 라디칼 소거능을 측정하기 전에 반응액을 에탄올로 희석하여 $735 \mathrm{~nm}$ 에서 흡광도 값이 $0.70 \pm 0.03$ 이 되도록 맞춘 후, 식혜 시료 $100 \mu \mathrm{L}$ 를 96-well plate에 넣고 흡광도를 맞춘 $\mathrm{ABTS}$ 용액 $100 \mu \mathrm{L}$ 를 첨가한 후 $37^{\circ} \mathrm{C}$ 에서 30 분간 반응시켰다. Spectrophotometer를 사용하여 $732 \mathrm{~nm}$ 에서 흡광도를 측정하 고 아래 식에 의해 계산하였다.

\section{$\mathrm{ABTS}$ 라디칼 소거활성 $(\%)=$ $(1$ - 시료첨가구의 흡광도 / 시료 무 첨가구의 흡광도 $) \times 100$}

환원력은 식혜 시료 $1 \mathrm{~mL}$ 에 $200 \mathrm{mM}$ 인산 완충액( $\mathrm{pH}$ 6.6) $1 \mathrm{~mL}$ 와 $1 \%$ potassium ferricyanide $1 \mathrm{~mL}$ 를 차례로 가한 다음 $50^{\circ} \mathrm{C}$ 에서 20 분간 반응시켰다. 반응이 끝난 후에 $10 \%$ 
$\mathrm{TCA}$ 용액을 $1 \mathrm{~mL}$ 첨가하여 $13,500 \times g$ 에서 15 분간 원심분 리하여 상등액을 얻었다. 상등액 $1 \mathrm{~mL}$ 에 증류수 및 ferric chloride를 각각 $1 \mathrm{~mL}$ 씩 가하여 혼합한 후 $720 \mathrm{~nm}$ 에서 얻은 흡광도 값을 환원력으로 나타냈다.

\section{통계분석}

모든 결과는 3 회 반복실험에 대한 평균(mean) \pm 표준편차 (SD)로 나타내었다. 실험결과에 대한 통계처리는 R-Studio (Version 3.5.1, Boston, MA, USA)를 이용하여 평균과 표준 편차로 나타내었고, 각 처리군 간의 유의성에 대한 검증은 ANOVA를 이용하여 유의성을 확인한 후, $\mathrm{p}<0.05$ 수준에서 Duncan's multiple range test를 이용하여 분석하였다.

\section{결과 및 고찰}

\section{일반성분 함량}

볶은 돼지감자 추출액 함량을 달리하여 제조한 식혜의 수 분, 회분, 조단백질 및 조지방 측정 결과는 Table 2 와 같다. 돼지감자 추출액을 첨가하지 않고 제조한 식혜의 수분은 $87.93 \%$ 로 가장 높았고, 돼지감자 추출액 함량이 $25-100 \%$ 까 지 증가함에 따라 수분은 $86.51 \%$ 에서 $82.91 \%$ 로 감소하는 경향을 나타냈다. 이는 식혜 제조 시 사용하는 물을 돼지감자 추출액으로 대체하였는데, 돼지감자 추출액에는 순수한 물에 비해 가용성 고형분 함량이 높아 나타난 현상으로 사료된다. 회분 함량은 돼지감자 추출액을 첨가하지 않은 대조군에서는 $0.14 \%$ 였고, 돼지감자 추출액 함량에 비례하여 $0.24-0.53 \%$ 까 지 증가하였다. 조단백질 및 조지방 함량은 대조군과 돼지감 자 추출액 첨가에 따른 통계적으로 유의성 있는 차이는 관찰 되지 않았다. Lee(2016)의 연구에 따르면 볶은 돼지감자에는 수분 $10.67 \%$, 회분 $2.80 \%$, 조단백질 $7.83 \%$, 조지방 $1.23 \%$ 가 함유된 것으로 보고하고 있으며, 건조 돼지감자 및 추출물 (차)의 일반성분 함량은 돼지감자의 품종, 건조 및 볶음 시간, 온도, 추출 용매 등에 따라 차이를 나타냈다(Hwang 등,
2019; Jung과 Shin, 2016).

\section{당도, 산도, $\mathrm{pH}$ 및 탁도}

볶은 돼지감자 추출액 함량을 달리하여 제조한 식혜의 당 도, $\mathrm{pH}$, 산도 및 탁도 측정 결과는 Table 3과 같다. 돼지감자 추출액을 첨가하지 않고 제조한 식혜의 당도는 $10.1{ }^{\circ} \mathrm{Brix}$ 로 가장 낮았고, 돼지감자 추출액을 $25-100 \%$ 첨가하여 제조한 식혜의 당도는 11.1-15.1 ${ }^{\circ} \mathrm{Brix}$ 로 돼지감자 추출액 함량에 비 례하여 증가하였다. 식혜는 발아시킨 보리 싹을 건조시켜 분말 화한 엿기름과 고두밥이 당화 과정을 거치면서 효소(amylase) 에 의한 고두밥에 함유된 전분이 맥아당과 포도당으로 전환 되어 식혜의 당도가 높아지는 것으로 사료된다(Kim 등, 2000; Song과 Hwang, 2016). 또한, 돼지감자 추출물에는 과 당, 포도당, 설탕, 엿당 등이 함유되어 있고, 고온에서 볶는 과정을 거치면서 설탕은 과당과 포도당으로 분해될 수 있다 고 보고하고 있다(Hwang 등, 2019). 따라서 물 대신 첨가한 돼지감자 추출액 함량이 높아짐에 따라 당도가 증가한 것은 돼지감자에 함유된 당류에 의한 것으로 사료된다.

제조한 식혜의 산도를 측정한 결과, 돼지감자 추출액을 첨 가하지 않은 식혜는 $0.08 \%$ 의 산도를 나타냈고, 돼지감자 추 출액 함량이 $25-100 \%$ 로 증가함에 따라 산도도 $0.11 \%$ 에서 $0.21 \%$ 로 증가하였다. 식혜의 $\mathrm{pH}$ 는 돼지감자 추출액 함량에 비례하여 감소하였다. 즉, 돼지감자 추출액을 첨가하지 않고 제조한 식혜의 $\mathrm{pH}$ 는 5.56 으로 가장 높았고, 돼지감자 추출액 함량이 25-100\%로 증가함에 따라 $\mathrm{pH}$ 는 5.49에서 5.38로 낮 아졌다. 돼지감자에는 oxalic acid, citric acid, malic acid, succinic acid, tartaric acid, fumaric acid 등의 유기산이 함유 되어 있고, 감자의 품종, 저장기간, 저장온도에 따라 유기산 조성이 다르고, 흰색보다는 자색 돼지감자의 유기산 함량이 높은 것으로 알려져 있다(Bushway 등, 1984; Jung과 Shin, 2017). 돼지감자에 함유된 유기산에 의해 식혜에 첨가하는 돼지감자 추출물 첨가량이 증가할수록 식혜의 산도가 높아지 고, $\mathrm{pH}$ 가 감소한 것으로 사료된다. 선행연구에 따르면 식혜

Table 2. Proximate composition of 'Sikhye' made with different amounts of Jerusalem artichoke extract

\begin{tabular}{ccccc}
\hline & \multicolumn{4}{c}{ Jerusalem artichoke extract (\%) } \\
\cline { 2 - 5 } Measurement & 0 & 25 & 50 & 100 \\
\hline Moisture & $87.93 \pm 0.13^{1) \mathrm{a}}$ & $86.51 \pm 0.13^{\mathrm{b}}$ & $85.69 \pm 0.14^{\mathrm{c}}$ & $82.91 \pm 0.17^{\mathrm{d}}$ \\
Ash & $0.14 \pm 0.03^{\mathrm{d}}$ & $0.24 \pm 0.01^{\mathrm{c}}$ & $0.34 \pm 0.04^{\mathrm{b}}$ & $0.53 \pm 0.01^{\mathrm{a}}$ \\
Crude protein & $0.29 \pm 0.01^{\mathrm{NS}}$ & $0.28 \pm 0.02^{\mathrm{NS}}$ & $0.26 \pm 0.01^{\mathrm{NS}}$ & $0.28 \pm 0.01^{\mathrm{NS}}$ \\
Crude fat & $0.08 \pm 0.00^{\mathrm{NS}}$ & $0.05 \pm 0.02^{\mathrm{NS}}$ & $0.09 \pm 0.05^{\mathrm{NS}}$ & $0.11 \pm 0.02^{\mathrm{NS}}$ \\
\hline
\end{tabular}

${ }^{1)}$ All values are mean $\pm \mathrm{SD}$ of triplicate experiments.

a-d Means with different superscript letters in a row are significantly different at $\mathrm{p}<0.05$.

${ }^{\mathrm{NS}}$ No significant. 
Table 3. Sugar content, pH, acidity and turbidity of 'Sikhye' made with different amounts of Jerusalem artichoke extract

\begin{tabular}{ccccc}
\hline & \multicolumn{4}{c}{ Jerusalem artichoke extract (\%) } \\
\cline { 2 - 5 } Measurement & 0 & 25 & 50 & 100 \\
\hline Sugar content ( ${ }^{\circ}$ Brix) & $10.1 \pm 0.00^{1) \mathrm{d}}$ & $11.1 \pm 0.00^{\mathrm{c}}$ & $12.2 \pm 0.00^{\mathrm{b}}$ & $15.1 \pm 0.00^{\mathrm{a}}$ \\
$\mathrm{pH}$ & $5.56 \pm 0.01^{\mathrm{a}}$ & $5.49 \pm 0.02^{\mathrm{b}}$ & $5.46 \pm 0.00^{\mathrm{c}}$ & $5.38 \pm 0.01^{\mathrm{d}}$ \\
Acidity (\%) & $0.08 \pm 0.00^{\mathrm{d}}$ & $0.11 \pm 0.00^{\mathrm{c}}$ & $0.14 \pm 0.00^{\mathrm{b}}$ & $0.21 \pm 0.00^{\mathrm{a}}$ \\
Turbidity (absorbance) & $0.09 \pm 0.00^{\mathrm{d}}$ & $0.17 \pm 0.00^{\mathrm{c}}$ & $0.25 \pm 0.00^{\mathrm{b}}$ & $0.41 \pm 0.00^{\mathrm{a}}$ \\
\hline
\end{tabular}

${ }^{1)}$ All values are mean $\pm \mathrm{SD}$ of triplicate experiments.

${ }^{a-d}$ Means with different superscript letters in a row are significantly different at $\mathrm{p}<0.05$.

에 첨가한 조릿대 추출물(Seo, 2016)과 헛개나무 추출물 (Kim 등, 2007)의 첨가비율이 증가함에 따라 식혜의 산도는 증가하고 $\mathrm{pH}$ 가 감소하여 본 연구와 유사한 결과를 나타냈다. 반면에, 인진쑥 추출물(Song과 Hwang, 2016)과 섬애약쑥 추 출물(Shin 등, 2017)을 식혜에 첨가한 경우는 첨가량에 비례 하여 $\mathrm{pH}$ 가 증가하여 본 결과와 차이를 보여, 첨가하는 부재 료의 유기산 함량 및 $\mathrm{pH}$ 에 의해 식혜의 산도와 $\mathrm{pH}$ 가 영향을 받는 것을 확인하였다.

제조한 식혜의 탁도를 측정한 결과, 돼지감자 추출액을 첨 가하지 않고 제조한 식혜의 탁도는 0.09 로 가장 낮았고, 돼지 감자 추출액 함량이 $25-100 \%$ 로 높아짐에 따라 0.17-0.41로 증가하였다. 탁도는 식혜 액의 흐림 정도를 나타내고, 일반적 으로 탁도가 낮은 것이 맑고 투명하므로 선호도가 높다고 알 려져 있다(Shin 등, 2017). 식혜 제조 시 사용하는 물의 양에 비해 엿기름이나 고두밥의 비율이 높거나 물 대신 각종 추출 물이 첨가됨에 따라 고형분 함량이 증가하여 탁도가 증가하 는 것으로 보고되고 있다(Hwang과 Sohn, 2020; Kim과 Park, 2012). 섬애약쑥(Shin 등, 2017), 조릿대(Seo, 2016), 인진쑥 (Song과 Hwang, 2016)을 추출물의 형태로 첨가하여 제조한
식혜에서도 물 대신 첨가한 추출물 함량이 증가함에 따라 탁 도가 증가하여 본 연구와 유사한 경향을 나타냈다. 특정 식물 추출물의 경우는 당화효소의 작용을 방해한다는 보고(Shin 등, 2017)가 있으므로 부재료를 첨가할 때는 식혜의 품질을 저하시키지 않는 적절한 수준에서 첨가량을 정하는 것이 필 요하다.

\section{색도 측정}

돼지감자 추출액을 첨가하여 제조한 식혜의 상등액과 밥 알의 색도를 측정한 결과는 Table 4 와 같다. 식혜 상등액과 밥알 모두에서 돼지감자 추출액을 첨가하지 않고 제조한 식 혜에 비해 돼지감자 추출액 함량이 증가함에 따라 명도 $\left(\mathrm{L}^{*}\right)$ 가 감소하였다. 적색도 $\left(\mathrm{a}^{*}\right)$ 는 대조군에 비해 돼지감자 추출액 을 첨가하여 제조한 식혜에서 높게 나타났고, 돼지감자 추출 액 함량에 비례하여 $\mathrm{a}^{*}$ 값이 증가하였다. 황색도 $\left(\mathrm{b}^{*}\right)$ 는 돼지 감자 추출액을 첨가하지 않고 제조한 식혜물과 밥알에서 각 각 2.03 및 6.89 로 나타났고, 식혜 상등액의 황색도는 대조군 에서 $2.03,25 \%$ 돼지감자 추출액 첨가군에서는 12.36 으로 증 가하였고, 돼지감자 추출액 $50 \%$ 및 $100 \%$ 첨가군에서는 각

Table 4. Changes in Hunter's color value of 'Sikhye' made with different amount of Jerusalem artichoke extract

\begin{tabular}{|c|c|c|c|c|c|}
\hline \multirow{2}{*}{\multicolumn{2}{|c|}{ Measurement }} & \multicolumn{4}{|c|}{ Jerusalem artichoke extract (\%) } \\
\hline & & 0 & 25 & 50 & 100 \\
\hline \multirow{3}{*}{ Liquid } & $\mathrm{L}$ & $51.81 \pm 0.05^{1) \mathrm{a}}$ & $47.50 \pm 0.03^{\mathrm{b}}$ & $44.67 \pm 0.03^{\mathrm{b}}$ & $41.92 \pm 0.01^{\mathrm{c}}$ \\
\hline & $\mathrm{a}$ & $0.35 \pm 0.02^{\mathrm{d}}$ & $0.42 \pm 0.01^{\mathrm{c}}$ & $2.38 \pm 0.02^{\mathrm{b}}$ & $5.22 \pm 0.02^{\mathrm{a}}$ \\
\hline & $\mathrm{b}$ & $2.03 \pm 0.03^{\mathrm{c}}$ & $12.36 \pm 0.02^{\mathrm{b}}$ & $14.78 \pm 0.08^{\mathrm{a}}$ & $14.03 \pm 0.05^{\mathrm{a}}$ \\
\hline \multirow{3}{*}{ Solid } & $\mathrm{L}$ & $47.64 \pm 0.21^{\mathrm{a}}$ & $41.49 \pm 0.09^{\mathrm{b}}$ & $39.29 \pm 0.23^{\mathrm{c}}$ & $37.47 \pm 0.13^{\mathrm{d}}$ \\
\hline & $\mathrm{a}$ & $1.65 \pm 0.17^{\mathrm{c}}$ & $1.69 \pm 0.16^{\mathrm{c}}$ & $2.16 \pm 0.11^{b}$ & $2.44 \pm 0.12^{\mathrm{a}}$ \\
\hline & $\mathrm{b}$ & $6.89 \pm 0.06^{\mathrm{a}}$ & $7.02 \pm 0.46^{\mathrm{a}}$ & $7.31 \pm 0.09^{\mathrm{a}}$ & $6.54 \pm 0.31^{\mathrm{a}}$ \\
\hline
\end{tabular}

\footnotetext{
${ }^{1)}$ All values are mean $\pm \mathrm{SD}$ of triplicate experiments.

${ }^{\mathrm{a}-\mathrm{d}}$ Means with different superscript letters in a row are significantly different at $\mathrm{p}<0.05$.
} 
각 14.78 및 14.03 으로 다른 군에 비해 높게 나타났으나 통계 적으로 유의성은 나타나지 않았다. 돼지감자 추출액 함량이 25-100\%까지 증가함에 따라 식혜 밥알의 황색도는 6.547.31로 나타났고, 통계적인 유의성은 관찰되지 않았다.

식품의 색은 첨가하는 재료의 색에 영향을 받고, 부재료 함량이 많을수록 명도가 낮아지는 것으로 알려져 있다(Shin 과 Chung, 2019). 볶은 돼지감자를 물로 추출하면 갈색을 나 타내는데, 이로 인해 돼지감자 추출액 함량에 비례하여 식혜 물의 명도는 감소하고, 적색도와 황색도가 증가한 것으로 사 료된다. 돼지감자 분말을 첨가하여 제조한 묵(Kim 등, 2015), 부침가루(Kim 등, 2013), 만두피(Jung, 2015)에서도 돼지감 자 첨가량이 증가함에 따라 명도는 감소하고, 적색도와 황색 도가 증가하여, 본 연구 결과와 유사한 경향을 나타냈다.

\section{총폴리페놀 및 총플라보노이드 함량 분석}

돼지감자 추출액 첨가 식혜의 총폴리페놀, 총플라보노이 드 및 총 안토시아닌 함량 분석결과는 Table 5 와 같다. 돼지 감자 추출액을 첨가하지 않고 제조한 식혜의 총폴리페놀 함 량은 식혜 $100 \mathrm{~mL}$ 당 gallic acid를 기준으로 $77.26 \mathrm{mg} / \mathrm{GAE}$ 이었고, 돼지감자 추출액 함량에 비례하여 식혜에 함유된 총 폴리페놀 함량이 증가하였다. 즉, 돼지감자 추출액을 $25 \%$, $50 \%$ 및 $100 \%$ 첨가하여 제조한 식혜에서 총폴리페놀 함량은 각각 $138.10,180.87$ 및 $240.40 \mathrm{mg} \mathrm{GAE} / 100 \mathrm{~mL}$ 로 이는 돼 지감자 추출액을 첨가하지 않은 식혜에 비해 총폴리페놀 함 량이 1.78-3.11 배까지 증가한 수치였다.

돼지감자 추출액를 첨가하지 않고 제조한 식혜의 총플라 보노이드 함량은 중량 $1 \mathrm{~g}$ 당 quercetin을 기준으로 $20.00 \mathrm{mg}$ 이었고, 돼지감자 추출액 첨가량에 비례하여 식혜의 총플라 보노이드 함량도 증가함을 확인하였다. 즉, 물 대신 돼지감자 추출액을 $25 \%, 50 \%$ 및 $100 \%$ 첨가한 식혜의 총플라보노이 드 함량은 각각 $50.65 \mathrm{mg}, 82.76 \mathrm{mg}$ 및 $140.63 \mathrm{mg} \mathrm{QE} / 100$ $\mathrm{mL}$ 로 확인되었다. 이는 돼지감자 추출액을 첨가하지 않은 식혜에 비해 총플라보노이드 함량이 2.53-7.03배까지 증가한 수치였다. 돼지감자 분말을 첨가하여 제조한 부침가루(Kim 등, 2013), 스펀지케이크(Kim 등, 2014), 묵(Kim 등, 2015)
등에서도 돼지감자 분말을 첨가할수록 총폴리페놀 및 총플라 보노이드 함량이 증가하는 것으로 나타나, 본 연구와 유사한 경향을 보였다.

선행연구에 의하면 돼지감자의 총폴리페놀은 품종, 건조 조건 등에 따라 차이가 있으며, 저온의 열처리에서는 안정하 고, $180-200^{\circ} \mathrm{C}$ 의 고온 열처리 조건에서도 열에 의해 쉽게 추 출되어 나오고(Jeong 등, 2011), 불용성인 페놀 화합물이 고 분자 화합물로부터 분리되어 유리형 페놀 화합물의 함량이 증가하는 것으로 보고하고 있다(Hong 등, 1998; Wang 등, 2020). 총플라보노이드의 경우 상온이나 저온 추출보다 150$200^{\circ} \mathrm{C}$ 의 고온에서 90 분 이상 추출했을 때 quercetin을 기준으 로 시료 $1 \mathrm{~g}$ 당 4.33-13.39 mg까지 함량이 증가하였다(Jeong 등, 2011). 건조된 돼지감자에는 catechin, chlorogenic acid, vanillic acid, epicatechin, salicylic acid, esculin 등의 약 22 종의 폴리페놀 화합물과 kaempferol, kaempferol gluconate, rutin, rhamnazin, hymenoxin, silymarin, nobiletin 등의 플라 보노이드 화합물을 함유하고 있는 것으로 보고되고 있다 (Tchong 등, 2006; Wang 등, 2020).

\section{항산화 활성 측정}

돼지감자 추출액을 첨가하여 제조한 식혜의 항산화 활성 을 측정한 결과는 Table 6 에 나타내었다. DPPH 라디칼 소거 활성은 돼지감자를 첨가하지 않은 대조군에서 $16.60 \%$ 로 나 타났고, 돼지감자 추출액을 $25-100 \%$ 까지 첨가한 식혜의 $\mathrm{DPPH}$ 라디칼 소거활성은 47.50-81.14\%까지 증가하였고, 이 는 돼지감자 추출액을 첨가하지 않은 식혜에 비해 $\mathrm{DPPH}$ 라 디칼 소거활성이 2.86-4.89배까지 증가한 수치였다. ABTS 라디칼 소거활성도 돼지감자 추출액 첨가량에 비례하여 높아 지는 경향을 보였다. 돼지감자 추출액을 첨가하지 않은 식혜 의 ABTS 라디칼 소거활성은 $15.29 \%$ 였고, 돼지감자 추출액 을 25-100\%까지 첨가하여 제조한 식혜에서는 32.83-71.58\% 의 ABTS 라디칼 소거능을 보였다. 이는 돼지감자 추출액을 첨가하지 않은 식혜에 비해 돼지감자 추출액을 25-100\%까지 첨가하여 식혜를 제조하면 $\mathrm{ABTS}$ 라디칼 소거활성이 2.15-4.68 배까지 증가시킬 수 있음을 확인하였다. 환원력도 돼지감자

Table 5. Total polyphenol and total flavonoid contents of 'Sikhye' made with different amount of Jerusalem artichoke extract

\begin{tabular}{ccccc}
\hline & \multicolumn{4}{c}{ Jerusalem artichoke extract $(\%)$} \\
\cline { 2 - 5 } Measurement & 0 & 25 & 50 & 100 \\
\hline Total polyphenol $\left(\mathrm{mg} \mathrm{GAE}^{1)} / 100 \mathrm{~mL}\right)$ & $77.26 \pm 1.39^{\mathrm{d}}$ & $138.10 \pm 3.85^{\mathrm{c}}$ & $180.87 \pm 3.47^{\mathrm{b}}$ & $240.40 \pm 3.91^{\mathrm{a}}$ \\
Total flavonoid $\left(\mathrm{mg} \mathrm{QE}^{2)} / 100 \mathrm{~mL}\right)$ & $20.00 \pm 0.90^{\mathrm{d}}$ & $50.65 \pm 1.80^{\mathrm{c}}$ & $82.76 \pm 1.81^{\mathrm{b}}$ & $140.63 \pm 3.12^{\mathrm{a}}$ \\
\hline
\end{tabular}

${ }^{\mathrm{a}-\mathrm{d}}$ Means with different superscript letters in a row are significantly different at $\mathrm{p}<0.05$.

${ }^{1)} \mathrm{GAE}$, gallic acid equivalent.

${ }^{2)} \mathrm{QE}$, quercetin equivalent. 
Table 6. Antioxidant activities of 'Sikhye' made with different amount of Jerusalem artichoke extract

\begin{tabular}{ccccc}
\hline \multirow{2}{*}{ Measurement } & \multicolumn{3}{c}{ Jerusalem artichoke extract (\%) } \\
\cline { 2 - 5 } & 0 & 25 & 50 & 100 \\
\hline DPPH radical scavenging activity (\%) & $16.60 \pm 1.95^{1) \mathrm{d}}$ & $47.50 \pm 2.88^{\mathrm{c}}$ & $62.74 \pm 0.58^{\mathrm{b}}$ & $81.14 \pm 2.16^{\mathrm{a}}$ \\
ABTS radical scavenging activity (\%) & $15.29 \pm 1.39^{\mathrm{d}}$ & $32.83 \pm 2.68^{\mathrm{c}}$ & $49.10 \pm 1.40^{\mathrm{b}}$ & $71.58 \pm 0.88^{\mathrm{a}}$ \\
Reducing power & $0.879 \pm 0.03^{\mathrm{b}}$ & $0.904 \pm 0.01^{\mathrm{b}}$ & $1.034 \pm 0.00^{\mathrm{a}}$ & $1.047 \pm 0.02^{\mathrm{a}}$ \\
\hline
\end{tabular}

${ }^{1)}$ All values are mean $\pm \mathrm{SD}$ of triplicate experiments.

${ }^{\mathrm{a}-\mathrm{d}}$ Means with different superscript letters in a row are significantly different at $\mathrm{p}<0.05$.

추출액 첨가량에 비례하여 증가하였다. 대조군에서는 0.879 의 흡광도를 나타냈고, 돼지감자 추출액을 $25-100 \%$ 까지 첨 가함에 따라 $720 \mathrm{~nm}$ 에서 흡광도 값이 0.904-1.047까지 증가 하는 것을 확인하였다. 최근 들어 조릿대(Seo, 2016), 인진쑥 (Song과 Hwang, 2016), 섬애약쑥(Shin 등, 2017)과 같이 폴 리페놀 및 플라보노이드가 풍부한 식물재료를 물로 추출하여 식혜에 첨가하여 항산화 활성을 증가시키려는 연구가 이루어 지고 있으며, 추출물의 함량에 비례하여 항산화 활성이 증가 하는 것을 확인하였다. 또한, 돼지감자를 첨가하여 제조한 부 침가루(Kim 등, 2013), 쌀 스펀지케이크(Kim 등, 2014), 설 기떡(Shin과 Chung, 2019)에서도 돼지감자 첨가량에 비례하 여 항산화 활성이 증가하는 것을 확인하였다.

\section{요 약}

본 연구에서는 볶은 돼지감자를 물로 추출하여 식혜 제조 시 물 함량 대비 25-100\% 비율로 첨가한 후에 식혜의 이화학 적 품질 특성, 기능성 성분의 함량 및 항산화 활성을 측정하여 돼지감자 추출액 첨가 식혜의 최적 배합비를 선정하고 제품화 가능성을 탐색하였다. 식혜의 수분 함량은 82.91-87.93\%로 돼지감자 추출액을 첨가하지 않은 식혜에서 가장 높았고, 돼 지감자 추출액 함량에 비례하여 수분이 감소하는 경향을 보 였다. 회분 함량은 대조군에서 $0.14 \%$ 로 가장 낮았고, 돼지감 자 추출액에 비례하여 $0.24-0.53 \%$ 까지 증가하였다. 식혜에 첨가한 돼지감자 추출액 함량에 따른 식혜의 조단백 및 조지 방 함량은 통계적으로 유의성 있는 차이가 없었다. 식혜에 첨 가한 돼지감자 추출액 함량에 비례하여 식혜의 당도, 산도 및 탁도는 증가하였고, $\mathrm{pH}$ 는 감소하는 경향을 보였다. 돼지감자 추출액 함량에 비례하여 식혜 물의 명도는 감소하였고, 적색 도와 황색도는 증가하였다. 식혜 밥알의 명도는 감소하였고, 적색도는 증가하였으나, 황색도는 통계적으로 유의성 있는 차이를 나타내지 않았다. 총폴리페놀과 총플라보노이드 함량 은 대조군에 비해 돼지감자 추출액 첨가량이 증가함에 따라 높게 나타났다. $\mathrm{DPPH}$ 및 $\mathrm{ABTS}$ 라디칼 소거활성과 환원력
으로 측정한 항산화 활성도 돼지감자 추출액 첨가량이 많아 질수록 증가하였다. 본 연구 결과는 돼지감자를 활용한 항산 화력이 보강된 식혜를 개발하기 위한 기초 자료로 활용할 수 있을 것으로 사료된다.

\section{Conflict of interests}

The authors declare no potential conflict of interest.

\section{ORCID}

Hye-Sook Kim https://orcid.org/0000-0002-2643-7476

Eun-Sun Hwang https://orcid.org/0000-0001-6920-3330

\section{References}

Ahmed W, Rashid S. Functional and therapeutic potential of inulin: A comprehensive review. Crit Rev Food Sci Nutr, 59, 1-13 (2019)

AOAC. Official Methods of Analysis of AOAC International. 16th ed, Association of Official Analytical Chemists, Washington DC, USA, p 1-26 (1995)

Baltacioglu C, Esin A. Chips production from Jerusalem artichoke (Helianthus tuberosus L.). Food Nutr Sci, 3, 1321-1328 (2012)

Ben Chekroun M, Amzile J, Mokhtari A, El Haloui NE, Prevost J, Fontanillas R. Comparison of fructose production by 37 cultivars of Jerusalem artichoke (Helianthus tuberosus L.). New Zeal J Crop Hort Sci, 24, 115-120 (1996)

Bornet FR. Undigestible sugars in food products. Am J Clin Nutr, 59, 763S-769S (1994)

Bushway RJ, Bureau JL, Mcganna DF. Determinations of organic acids in potatoes by high performance liquid 
chromatography. J Food Sci, 49, $76-77$ (1984)

Cheung LM, Cheung PC, Ooi VE. Antioxidant activity and total phenolics of edible mushroom extracts. Food Chem, 81, 249-255 (2003)

Choi YH, Kim KH, Kang MY. Varietal difference in processing and sensory characteristics of Sikhe in rice. Korean J Bread, 33, 65-72 (2001)

Hwang EG, Lee SH, Kim BK, Kim SJ, Ann YG, Doryoon $\mathrm{M}, \mathrm{Oh} \mathrm{SC}$. Components and function of artichoke tea prepared by steaming and drying method. J Korean Appl Sci Technol, 36, 1-12 (2019)

Hwang ES, Sohn EM. Quality characteristics and antioxidant activity of Sikhye made with different amount of aronia juice. J Korean Soc Food Sci Nutr, 49, 946-952 (2020)

Jeong HJ, Kim JS, Sa YJ, Kim MO, Yang J, Kim MH. Antioxidant activity and $\alpha$-glucosidase inhibitory effect of Jerusalem artichoke (Helianthus tuberosus) methanol extracts by heat treatment condition. Korean J Med Crop Sci, 19, 257-263 (2011)

Jung BM, Shin TS. Food components and antioxidant activities of dried Jerusalem artichoke with white and purple colors. J Korean Soc Food Sci Nutr, 45, 11141121 (2016)

Jung BM, Shin TS. Organic acids, free sugars, and volatile flavor compounds by type of Jerusalem artichoke. J Korean Soc Food Sci Nutr, 46, 822-832 (2017)

Jung MS. Quality characteristics of rice dumpling shell with Jerusalem artichoke (Helianthus tuberosus L.) powder. MS Thesis, Suncheon National University, Suncheon, Korea, p 27-36 (2015)

Kelly G. Inulin type prebiotics - A reivew: Part I. Altern Med Rev, 13, 315-329 (2008)

Kim GC, Kim HS, Jo IH, Kim JS, Kim KM, Jang YE. Qualitative characteristics and antioxidant activities of Buchimgaru supplemented with Jerusalem artichoke powder. J Korean Soc Food Sci Nutr, 42, 1065-1070 (2013)

Kim GS, Park GS. Quality characteristics of Sikhye prepared with Cnidium officinale Makino water extracts. J East Asian Soc Dietary Life, 22, 868-878 (2012)

Kim HH, Park GS, Jeon JR. Quality characteristics and storage properties of Sikhye prepared with extracts from Hovenia dulcis Thunb. J Food Cookery Sci, 23, 848-857 (2007)
Kim MH, Kim HY, Han JS, Ji EH, Kim AJ. Physicochemical analysis and quality characteristics of Jerusalem artichoke and Mook prepared with Jerusalem artichoke powder. Korean J Food Nutr, 28, 635-642 (2015)

Kim MK, Lee EJ, Kim KH. Effect of Helianthus tuberosus powder on the quality characteristics and antioxidant activity of rice sponge cakes. Korean J Food Culture, 29, 195-204 (2014)

Kim SK, Kim JM, Choi YB. Effect of Sikhye manufacturing conditions on the rice shape. Korean J Diet Cul, 15, 1-8 (2000)

Lee YL. Analysis of nutritional components and antioxidant activity of roasting Wooung and Jerusalem artichoke. Korean J Food Nutr, 29, 870-877 (2016)

Oyaizu M. Studies on product of browning reaction: Antioxidative activities of product of browning reaction prepared from glucosamine. Jap J Nutri, 44, 307-315 (1986)

Park EJ, Kim HJ, Kim JM, Chun HS. Antiulcerative effect of Sikhe on stomach ulcer induced by ethanol. J Korean Soc Food Sci Nutr, 26, 98-102 (1997)

Park GS. Optimization of muffin preparation upon addition of Jerusalem artichoke powder and oligosaccharide by response surface methodology. Korean J Food Cult, 29, 101-110 (2014)

Park HS. Quality characteristics of Sulgidduk by the addition of Jerusalem artichoke (Helianthus tuberosus L.) powder. Korean J Culinary Res, 16, 259-267 (2010)

Park HS, Yang KC, Yang KM. The effects of medicinal herb-made Sikhe on damage and lipid levels of liver in rat fed high-cholesterol diets. J Life Sci, 19, 1104-1111 (2009)

Park HY, An NY, Ryu HK. The quality characteristics and hypoglycemic effect cookies containing Helianthus tuberosus powder. Korean J Community Living Sci, 24, 233-241 (2013)

Park LY. Quality characteristics and antioxidant activity of Sikhe prepared using hot water extracts of roasted coffee ground residue. Korean J Food Sci Technol, 46, 470-476 (2014)

Park SI. Application of green tea powder for Sikhe preparation. Korean J Food Nutr, 19, 227-233 (2006)

Re R, Pellegrini N, Proteggente A, Pannala A, Yang M, Rice-Evans C. Antioxidant activity applying an improved 
ABTS radical cation decolorization assay. Free Rad Biol Med, 26, 1231-1237 (1999)

Seo HJ, Jung SH, Hwang JH. Characteristics of Sikhe produced with malt of naked barley, covered barley and wheat. Korean J Food Sci Technol, 29, 716-721 (1997)

Seo JH. Quality characteristic of Sikhye prepared with Sasa borealis extracts. Korean J Food Preserv, 23, 599-604 (2016)

Seo JH, Lee KS, Oh SH, Kim MR. The opinion of food and nutrition specialists about the qualities of commercial Sikhe. J Korean Soc Food Sci Nutr, 31, 945-951 (2002)

Shao T, Yu Q, Zhu T, Liu A, Gao X, Long X, Liu Z. Inulin from Jerusalem artichoke tubers alleviates hyperglycaemia in high-fat-diet-induced diabetes mice through the intestinal microflora improvement. $\mathrm{Br} \mathrm{J}$ Nutr, 123, 308-318 (2020)

Shin JY, Byun MW, Noh BS, Choi EH. Noodle characteristics of Jerusalem artichoke added wheat flour and improving effect of texture modifying agents. Korean J Food Sci Technol, 23, 538-545 (1991)

Shin JY, Woo YU, Jo YL, Seo WT, Choi JS. Quality characteristics of Sikhye prepared by different ratio of Seomaeyaksuk (Artemisia argyi H) extract. Korean J Food Preserv, 24, 196-205 (2017)

Shin MH, Chung NY. Quality evaluation of brown rice Sulgidduk added with Jerusalem artichoke powder. J East Asian Soc Diet Life, 29, 112-119 (2019)

Slimestad R, Seljaasen R, Meijer K, Skar SL. Norwegian- grown Jerusalem artichoke (Helianthus tuberosus L.): Morphology and content of sugars and frutooligosaccharides in stems and tubers. J Sci Food Agric, 90, 956-964 (2010)

Song KJ, Hwang ES. Quality characteristics and antioxidant activities of Sikhye added with Artemisia capillaris extracts. J Korean Soc Food Sci Nutr, 45, 1630-1637 (2016)

Suh HJ, Chung SH, Whang JH. Characteristics of Sikhye produced with malt of naked barley, covered barley and wheat. Korean J Food Sci Technol, 29, 716-721 (1997)

Tchong M, Barwald G, Annemuller G, Gleischer LG. Separation and identification of phenoilic compounds in Jerusalem artichoke (Helianthus tuberosus L.). Sci Aliments, 26, 394-408 (2006)

Wang Y, Zhao Y, Xue F, Nan X, Wang H, Hua D, Liu J, Yang L, Jiang L, Xiong B. Nutritional value, bioactivity, and application potential of Jerusalem artichoke (Helianthus tuberosus L.) as a neotype feed resource. Animal Nutr, 6, 429-437 (2020)

Yang JW, Jung SK, Song KM, Kim YH, Lee NH, Hong SP, Lee KH, Kim YE. Quality characteristics of Sikhye added with mulberry (Morus alba L.) fruit concentrate. J East Asian Soc Dietary Life, 26, $44-54$ (2016)

Yang JW, Kim YE, Lee KH. Physicochemical characteristics and antioxidant activities of Sikhye made with pigmented rice. J East Asian Soc Dietary Life, 25, 830-841 (2015) 